\title{
Factors Affecting the Meaning in Life of Teachers
}

\author{
Suyatno ${ }^{1}$, Dholina Inang Pambudi ${ }^{2}$, Ganis Amurdawati ${ }^{3}$, Wantini ${ }^{4}$, \\ Mei Vita Romadon Ningrum ${ }^{5}$
}
1 Ahmad Dahlan University, Department of Education Management, 42 Pramuka St., Sidikan, Yogyakarta, Indonesia, suyatno@pgsd.uad.ac.id
2 Ahmad Dahlan University, Department of Primary Teacher Education, 19 Ki Ageng Pemanahan St., Sorosutan, Yogyakarta, Indonesia, dholina.pambudi@pgsd.uad.ac.id
3 Semarang State University, Department of Primary Teacher Education, Kelud Utara III St., Semarang, Indonesia, ganis.amorr@gmail.com
4 Ahmad Dahlan University, Department of Islamic Education, 42 Pramuka St., Sidikan, Yogyakarta, Indonesia, wantini@mpai.uad.ac.id
5 Mulawarman University, Department of Geography Education, Muara Pahu Kampus Gunung Kelua St., Samarinda, Indonesia,mei_vita88@yahoo.com

\begin{abstract}
This study aims to investigate the various models that affect the meaning in life of teachers. This is a quantitative study with data randomly obtained from a sample of 100 teachers at East Kalimantan, Indonesia. The results showed that self-actualization and self-transcendence are crucial factors which have an impact on the meaning in life of teachers. The policy makers need to utilize the results from this study to design various programs and training for the development of meaning in life of teachers.
\end{abstract}

Keywords: meaning in life, self-actualization, self-transcendence, teacher.

\section{Introduction}

Over the last two decades, the meaning of life has received tremendous attention from three scientific groups, namely psychology, logotherapy, and mental health (Steger et al., 2013; Newman et al., 2018). According to various researches, it meaning in life positively influence the indicators of life and performance, as well as those that tend to reduce their negative emotions. Empirically, it has different meanings, which are relative to one another (Nezlek et al., 2017; Tov \& Lee, 2016) because it is influenced by situational 
factors that enhance subjective experiences (Heintzelman et al., 2013; Kay et al., 2014). Therefore, the meaning of life enables teachers' to gain positive and negative experiences (Tov \& Lee, 2016; King et al., 2006) and also from traumatic incidents (Bonanno et al., 2005). Despite its subjective and unique nature, many authors tried to identify common themes among individuals, with the meaning discussed in the theoretical and academic terms of literature (Batthyany \& Russo-Netzer, 2014; Wong, 2012).

Previous studies were carried out on this topic by applying various approaches. A personal review of the impact and interventions of the meaning in life and its effect on depressive symptoms was conducted by Westerhof et al. (2010). This study was conducted by comparing two different groups. The first consists of 83 adults who received a life review, while the control group comprises of 88 people watched a video on the art of growing older. According to the results, the group that received life review treatment developed several personal meanings compared to the control group. Therefore the authors concluded that this approach is used to support parents in their search for the meaning of life through reviews, and helps in reducing symptoms of depression. Similar research involving 731 respondents in the United States was also carried out by Park et al. (2010). The results showed that the presence of meaning was positively is related to satisfaction, and happiness, as well as having both positive and negative influences on depression, while the general search for meaning had opposite correlated patterns.

Also, there are few empirical studies with similar topics in the educational context, related to how the variable is associated with the way teachers carry out their profession. However, previous studies on this topic were mostly carried out in the fields of psychology, mental health, and logo-therapy. In fact, the literature concerning the need for the meaning of life in education has been reported by several experts, in addition it improves the teaching professionalism (Suyatno, et al. 2019). According to the research conducted by Tutu (2007) and Maree (2019), the ability of teachers to discover the meaning and purpose of their lives has become an urgent need in the learning process at school. Suyatno et al. (2019) stated that teachers with certain values tend to have an impact on the quality of teaching which important factors are that influences professionalism. Value is the crystallization of the searching process involved in the meaning of one's life (Frankl, 2006).

The purpose of this research is to identify the factors that influence the meaning of teacher's life. In accordance with the initial evidence that has been reviewed and literatures on the fields of psychology, logo-therapy, and mental health, it is discovered that self-actualization and self-transcendence are two variables predicted to influence the meaning of one's life. The results from this study are expected to provide more scientific insights that tend to efficiently make teachers' life more meaningful. Furthermore, it also encompasses the lack of scientific literature in the educational fields. Therefore, the main purpose of this research is to explore the factors that influence the meaning in life of teachers by using a questionnaire at junior high school education in East Kalimantan, Indonesia. 


\section{The Research Question}

Based on the background of the problem above, the research question is as follows: what factors affect the meaning in life of teachers at junior high school, East Kalimantan?

\section{Literature Review and Hypothesis Development}

\section{Meaning in Life for Educators}

The meaning of life is actually important for people in various professions. It discovers an individual effort to improve their quality of life. Frankl (2006) stated that the meaning of life is one's appreciation of how much they have developed their various potentials and the extent they have achieved goals. Cohen and Cairns (2012) reported that individuals with high level of meaning in life tend to avoid the effects of negative emotions such as stress, anxiety, and depression.

Furthermore, the meaning of life is also believed to be influenced by factors other than affective experience (Heintzelman \& King, 2014; Waytz et al., 2015). Hicks and King (2009) stated that subjective experience is characterized by three aspects. The first, requires a sense of purpose, this simply implies that one's life and activities needs to be directed towards important goals (Wong, 2012). Secondly, it involves the belief that one's existence has values or significances beyond the present moment (Frankl, 2006; Steger et al., 2006). Thirdly, it implies the coherence or completeness, of life required by individuals (Wong \& Wong, 2012).

Steger et al. (2006) reported that meaning in life is understood from at least two dimensions. Firstly, the extent to which it is discovered or experienced by a person (referred to as presence) and secondly, the extent to which an individual searches for meaning in life (this is referred to as search). An instrument consisting of 5 indicators of attendance (The individual understands the meaning of life) and 5 of search (The individual searched for the meaning of life) were developed to measure these two dimensions (Steger et al., 2006).

Lee (2015) stated that meaning in work is influenced by one's cognitive change and has a positive impact on the personal experience of colleagues and institutions. Wong and Wong (2012) reported several aspects such as goals, understanding, responsible actions, and evaluations (positive) of one's life in their PURE model. Tov \& Lee (2016) stated that there are five ways to focus on positive things in order to determine meaningful, side benefits, make social comparisons, imagining worse situations, forgetting the negative ones, and redefining.

Meaning in life is one of the factors that tend to affect the quality of one's performance. This premise is supported by the research carried out by Heintzelman et al. (2013) which stated that people that consider their lives as very meaningful are better in several ways, compared to their counterparts. In accordance with other researchers, it was also stated 
that individuals that consider their lives meaningful are directly proportional to those with higher quality life (Littman-Ovadia \& Steger, 2010), better job adjustments (Krause, 2007), higher levels of optimism (Steger et al., 2009), experiences lower psychological disorders (Mascaro \& Rosen, 2005; Owens et al., 2009; Steger \& Kashdan, 2007), and slower age-related cognitive decline (Boyle et al., 2010).

\section{Self-Actualization and Meaning in Life}

The theory of self-actualization and hierarchy of needs was popularized by a psychologist, Maslow (1970) in increasing life needs. This hierarchy starts with the physiological needs such as security, social, respect, to self-actualization which is the highest development of one's talents. Maslow (1987) further stated that self-actualization is the maximum utilization of one's talents and potential to fulfill their needs. In addition, this process leads to the discovery of identity and the development of human potentials. Therefore, it is the ability of a person to become whatever they desire based on their potentials (Maslow, 1970). According to Maslow (1987), reported that self-actualization is influenced by universal factors as follows: Firstly, the ability to view life clearly, simply and objectively. Secondly, it is the ability of people to carry out their functions, duties and obligations towards work with a great sense of responsibility. Thirdly, psychological independence which is the capability of making decisions not bound by public opinion.

Some literatures reported the preliminary evidence of the relationship between selfactualization and meaning in one's life. Fave et al. (2013) stated that self-actualization is a sub-category of personal growth, harmony and well-being, which is approximately the main source at $8.5 \%$. This is in accordance with the research conducted by Debats (1999) which also stated that self-actualization is one of the factors that influences the meaning in one's life. Furthermore, four factors greatly influence self-actualization namely relationships, long life, work, and personal well-being. Subsequently, service, belief, and materiality are 3 factors with a lesser effect than self-actualization. Based on the research conducted on psychiatric patients, Debats (1999) reported that self-actualization is a source of meaningful life and it is more important than the other aspects.

Baum and Stewart (1990) stated that a total of $72 \%$ of both men and women find their works meaningful. However, the difference lies in the order associated with other factors. For men, work is the first source of a meaningful life while for women, it is the third source with $78 \%$ child birth and $77 \%$ associated with love and marriage. Schnell (2009) discovered that women exhibited more Vertical Self-Transcendence, Well-Being, and Relatedness than men. On the contrary, men were reported to display more selfactualization than women. It was further stated that meaningful life is an important factor that is positively influenced by self-actualization. A research conducted by Kenrick (2017) showed that self-actualization is often synonymous with gaining meaning in life.

The researches and theories stated above showed that self-actualization with or without other factors influence the meaning of one's life. Despite the fact that those studies were 
not conducted in the field of science education, therefore, the theories became the basis for developing the hypotheses in this research.

\section{Hypothesis 1:}

There is a positive and significant influence between self-actualization and meaning in life of teachers.

\section{Self-Transcendence and Meaning in Life}

Self-transcendence is an individual's level of need and it surpasses self-actualization. It is also a person's sense of relatedness in accordance with transcendent. In certain societies, self-transcendence is highly manifested in one's diversity and spirituality (Haugan, 2012). Furthermore the theory of self-transcendence which started when Maslow observed certain people with fulfilled criteria for self-actualization. The observation results showed that individuals with self-actualization had higher needs and values compared to those that failed to complete the stages. The needs and values are forms of encouragement in order for humans to connect with a higher power beyond themselves, as well as help others realize and develop their potentials. This motivational condition became the representative definition of the self-transcendence concept.

Maslow (1970) stated that the level of achievement of ones'self-transcendence needs was constructed based on two key elements, the peak and plateau experiences. These strategies undergo several situations such as happiness, deep joy, feeling at else with the universe, and a higher awareness of beauty. Conversely, when people experience these moments, they become aware of the existence and brain in optimal condition thereby, leading to the ability to achieve set intellectual goals. This moment usually last for a short time. However, certain people have the ability to remain in the peak experience phase for a longer period. This condition at a higher level is referred to as the plateau experience. Maslow's self-transcendence theory which was later developed in three disciplines namely transpersonal psychology, personality and nursing theories have the same basic concept with spirituality inherent in every human being and the fulfillment positively correlated with individuals' well-being (Smith \& Liehr, 2008).

Some literature reviews and empirical research has provided preliminary evidence on the relationship between self-transcendence and meaning in life. Frankl (2006) stated that self-transcendence is an innate desire to discover meaning in human life. Correspondingly, Schnel (2010) reported that self-transcendence is a pre-condition that is needed towards meaning in life. Venter (2016) stated that Maslow's concept is the most accurate description of the type of people that are presently needed in the world with people responsible for their freedom that transcends boundaries, and people that have discovered ways to shape the future of the world. Meanwhile, Snow (2018) reported that self-transcendence is a "fundamental" or "existential" expectation required by humans to discover meaning in life. In addition, the achievement of self-transcendence causes a 
person to have a better understanding of the various situations around their environment. Therefore, its achievement shows individual maturity.

Several empirical researches have been carried out on self-transcendence. For example, it was reported that self-transcendence has an indirect effect on the relationship between meaning in life and prejudice. Subsequently, meaning in life also functions as a mediator between self-transcendence and prejudice (Florez et al., 2019). It was further discovered that self-transcendence has the ability to reduce a persons' level of depression through mediation. Therefore, spirituality is the act of building self-transcendence which is an important predictor associated with depression. Kang et al. (2018) also reported that self-transcendence refers to a change in mindset, from a focus on personal interests to the welfare of others). Anderson et al. (2018) stated that moral praise is one of the approaches used to increase an individual's self-transcendence.

The evidences sourced from literature reviews and empirical researches showed a relationship between self-transcendence and meaning in life. Although, these studies were conducted outside the education field, it was used as the basis for developing this research hypothesis.

\section{Hypothesis 2:}

There is a positive and significant influence between self-transcendence and meaning in life of teachers.

\section{Hypothesis 3:}

There is a positive and significant simultaneous effect between self-actualization and self-transcendence on the meaning in life of teachers.

\section{Methods}

\section{The Types of Research}

This is a quantitative research with a survey approach used to examine the influence of independent and dependent variables. The survey approach was chosen because it is in accordance with the research problem which stated the effect of the relationship between the two predicted variables.

\section{Population and Sample}

The research population comprises of junior high school, teachers at East Kalimantan province. Data was obtained from a total of 100 teachers demographically, consisting of $53 \%$ men and $47 \%$ women, using stratified sampling technique. In addition, $10 \%$ of the respondents had undertaken graduate-level education while the remaining $90 \%$ were 
undergraduates of their respective fields, therefore the research samples were teachers at the higher education levels. In terms of age, $60 \%$ of the teachers were within an age range of 31-50 years, therefore the respondents were considered to be matured and expected to understand the research details.

\section{Techniques and Data Collection Instruments}

Data were collected using a closed questionnaire that was distributed through the assistance of the principal. This study employed three different questionnaires, namely the meaning in life of the teacher, self-actualization, and self-transcendence. The meaning of life questionnaire is in accordance with attendance and search indicators which were developed into six items (Steger et al., 2006). Self-actualization consists of four aspects namely growth, potential achievement, self-fulfillment, and encouragement needs (Robbins \& Coulter, 2010). The self-transcendence questionnaire has seven indicators consisting of explicit religiosity, spirituality, unison with nature, social commitment, generativity, care, and health, each of which was developed into two items (Schnell \& Becker, 2006). The questionnaire items were tested based on two stages, 1) expert judgment test conducted by two professionals. The questionnaire was improved, based on suggestions, 2) the empirical validity test was carried out which obtained information that declared all items in the questionnaire valid and reliable. The questionnaire was made using a Likert scale of 1 to 4 .

\section{Data Analysis Technique}

The data analysis used in this study was multiple linear regression with SPSS version 2. This model was chosen to determine the partial or simultaneous effects of self-actualization and self-transcendence on meaning in life. Before the multiple regression model was used to test the hypothesis, class assumptions test was first conducted, including normality, linearity, multicollinearity, and heteroscedasticity. When all the requirements for researching a regression model have been fulfilled, data analysis was then conducted using the $\mathrm{T}$ and $\mathrm{F}$ test, regression equation, and the coefficient of determination. This was carried out to determine whether the hypothesis proposed in this study is accepted or not.

\section{Findings}

Simple and multiple regression analysis were used to test the research data. The simple regression was used to test the first and second hypotheses, while the multiple was used for the third. 


\section{Descriptive Statistical Analysis}

Table 1

Descriptive Statistics

\begin{tabular}{|c|c|c|c|c|c|c|c|}
\hline & \multirow[b]{2}{*}{$\begin{array}{c}\mathrm{N} \\
\text { Statistic }\end{array}$} & \multirow{2}{*}{$\begin{array}{c}\text { Mini- } \\
\text { mum } \\
\text { Statistic }\end{array}$} & \multirow{2}{*}{$\begin{array}{c}\text { Maxi- } \\
\text { mum } \\
\text { Statistic }\end{array}$} & \multirow[b]{2}{*}{$\begin{array}{l}\text { Mean } \\
\text { Statistic }\end{array}$} & \multirow{2}{*}{$\begin{array}{c}\text { Std. } \\
\text { Deviation } \\
\text { Statistic }\end{array}$} & \multicolumn{2}{|c|}{ Skewness } \\
\hline & & & & & & Statistic & $\begin{array}{l}\text { Std. } \\
\text { Error }\end{array}$ \\
\hline Meaning & 100 & 30 & 48 & 40.23 & 3.900 & .029 & .241 \\
\hline Actualization & 100 & 35 & 52 & 41.98 & 4.005 & .501 & .241 \\
\hline Transendence & 100 & 40 & 59 & 49.83 & 3.854 & .249 & .241 \\
\hline $\begin{array}{l}\text { Valid N } \\
\text { (listwise) }\end{array}$ & 100 & & & & & & \\
\hline
\end{tabular}

Table 1 showed that the average value indicates a tendency of 4.0, indicates the majority of respondents stated had a neutral response with the statement in the questionnaire.

\section{Normality Test}

The normality test was conducted using Kolmogorov-Smirnov for 100 research samples. The results of decision making were obtained when the sig value was $>0.05$. The results of the normality test are shown in table 2 .

Table 2

Normality Test Results

\begin{tabular}{llccc}
\hline & & $\begin{array}{c}\text { Meaning in } \\
\text { life }\end{array}$ & $\begin{array}{c}\text { Self- } \\
\text { Actualization }\end{array}$ & $\begin{array}{c}\text { Self- } \\
\text { Transcendence }\end{array}$ \\
\hline $\mathrm{N}$ & & 99 & 99 & 99 \\
\hline \multirow{2}{*}{ Normal Parameters ${ }^{\mathrm{a}, \mathrm{b}}$} & Mean & 40.26 & 44.99 & 56.41 \\
& Std. & 3.906 & 4.265 & 4.524 \\
& Deviation & & & .070 \\
Most Extreme & Absolute & .101 & .122 & .068 \\
Differences & Positive & .101 & .122 & -.070 \\
\hline Kolmogorov-Smirnov Z & Negative & -.090 & -.069 & .694 \\
Asymp. Sig. (2-tailed) & & 1.007 & 1.214 & .722 \\
\hline a. Test distribution is Normal. & .262 & .105 & \\
b. Calculated from data. & & & \\
\hline
\end{tabular}


The result of the meaning in life was $0.262>0.05$, which can be concluded that the data are normally distributed. Meanwhile, the result of Self-Actualization was $0.105>$ 0.05 , which can also be concluded that the data are normally distributed. Furthermore, the results of self-transcendence was $0.722>0.05$, which can be concluded that the data are normally distributed. In addition, the results of normality test for the research variables showed that the data were normally distributed, therefore this classic assumption test could be fulfilled.

\section{Linearity Test}

This linearity test was used to determine whether the variables have a significant linear relationship or not. Also, the decision to take the test was made when the deviation form linearity was $>0.05$. The results are shown in table 3 .

Table 3

The Linearity Test Results of Self-Actualization and Meaning in Life

\begin{tabular}{|c|c|c|c|c|c|c|c|}
\hline \multicolumn{8}{|c|}{ ANOVA Table } \\
\hline & & & $\begin{array}{l}\text { Sum of } \\
\text { Squares }\end{array}$ & df & $\begin{array}{c}\text { Mean } \\
\text { Square }\end{array}$ & $\mathbf{F}$ & Sig. \\
\hline \multirow{5}{*}{$\begin{array}{l}\text { Meaning in life } \\
\text { * Self-Actual- } \\
\text { ization }\end{array}$} & \multirow{3}{*}{$\begin{array}{l}\text { Between } \\
\text { Groups }\end{array}$} & (Combined) & 665.412 & 18 & 36.967 & 3.606 & .000 \\
\hline & & Linearity & 412.014 & 1 & 412.014 & 40.194 & .000 \\
\hline & & $\begin{array}{l}\text { Deviation } \\
\text { from Line- } \\
\text { arity }\end{array}$ & 253.398 & 17 & 14.906 & 1.454 & .134 \\
\hline & \multicolumn{2}{|c|}{ Within Groups } & 830.298 & 81 & 10.251 & & \\
\hline & \multicolumn{2}{|l|}{ Total } & 1495.710 & 99 & & & \\
\hline
\end{tabular}

The result of the deviation form linearity showed a sig value of $0.134>0.05$. Therefore, it can be concluded that there is a significant linear relationship between the self-actualization and meaning in life variables. The results are shown in table 4 .

Table 4 showed the linearity results of meaning in life and self-transcendence. Also, deviation form linearity result showed a sig. value of $0.932>0.05$. Therefore, it can be concluded that there is a significant linear relationship between the self-transcendence and meaning in life variables. 
Table 4

The Linearity Test Results of Self-transcendence and Meaning in Life

\begin{tabular}{|c|c|c|c|c|c|c|c|}
\hline \multicolumn{8}{|l|}{ ANOVA Table } \\
\hline & & & $\begin{array}{l}\text { Sum of } \\
\text { Squares }\end{array}$ & df & $\begin{array}{c}\text { Mean } \\
\text { Square }\end{array}$ & $\mathbf{F}$ & Sig. \\
\hline \multirow{5}{*}{$\begin{array}{l}\text { Meaning in life } \\
\text { Self-Transcend- } \\
\text { ence }\end{array}$} & \multirow{3}{*}{$\begin{array}{l}\text { Between } \\
\text { Groups }\end{array}$} & (Combined) & 507.055 & 20 & 25.353 & 2.026 & .014 \\
\hline & & Linearity & 377.505 & 1 & 377.505 & 30.165 & .000 \\
\hline & & $\begin{array}{l}\text { Deviation } \\
\text { from Line- } \\
\text { arity }\end{array}$ & 129.550 & 19 & 6.818 & .545 & .932 \\
\hline & \multicolumn{2}{|c|}{ Within Groups } & 988.655 & 79 & 12.515 & & \\
\hline & \multicolumn{2}{|l|}{ Total } & 1495.710 & 99 & & & \\
\hline
\end{tabular}

\section{Multicollinearity Test}

This classic assumption test was used to analyze the presence or absence of significant relationship between self-actualization and self-transcendence on meaning in life. Therefore, to ascertain these results, the tolerance and VIF values were analysed. The results of the multicollinearity test are shown in table 5 .

Table 5

Multicollinearity Test

\begin{tabular}{|c|c|c|c|}
\hline \multicolumn{4}{|c|}{ Coefficients $^{\mathrm{a}}$} \\
\hline & \multirow{2}{*}{ Model } & \multicolumn{2}{|c|}{ Collinearity Statistics } \\
\hline & & Tolerance & VIF \\
\hline \multirow{3}{*}{1} & (Constant) & & \\
\hline & Self-Actualization & .901 & 1.110 \\
\hline & Self-Transcendence & .901 & 1.110 \\
\hline \multicolumn{4}{|c|}{ a. Dependent Variable: Meaning in life. } \\
\hline
\end{tabular}

The results of self-actualization have a tolerance value of $0.901>0.10$ and a VIF value of $1.110<10$. Meanwhile, the results of self-transcendence have a tolerance value of $0.901>0.10$ and VIF value of $1.110<10$. Based on these, there are no signs of multicollinearity in the proposed regression model.

\section{Heteroscedasticity Test}

This classic assumption was used to test whether the proposed regression model does not occur heteroscedasticity. This was achieved by indicating the variance from the residual value of one observation to another. The heteroscedasticity in this study used the 
Glejser test. Therefore, when the sig. value was $>0.05$, heteroscedasticity does not occur. The results of the test are shown in table 6.

Table 6

Heteroscedasticity Test Results

Coefficients $^{\mathrm{a}}$

\begin{tabular}{|c|c|c|c|c|c|c|}
\hline & \multirow{2}{*}{$\begin{array}{c}\text { Model } \\
\text { B }\end{array}$} & \multicolumn{2}{|c|}{ Unstandardized Coefficients } & \multirow{2}{*}{$\begin{array}{l}\text { Standardized } \\
\text { Coefficients }\end{array}$} & \multirow{2}{*}{$\mathbf{t}$} & \multirow{2}{*}{ Sig. } \\
\hline & & Std. Error & Beta & & & \\
\hline \multirow{3}{*}{1} & (Constant) & 1.469 & 2.633 & & .558 & .578 \\
\hline & Self-Actualization & -.014 & .045 & -.034 & -.318 & .751 \\
\hline & Self-Transcendence & .028 & .043 & .069 & .646 & .520 \\
\hline
\end{tabular}

a. Dependent Variable: Abs_Res.

The results of self-actualization have a sig. value of $0.751>0.05$, which can be concluded that there are no signs of heteroscedasticity. Meanwhile, the results of self-transcendence have a sig. value of $0.520>0.05$, which can also be concluded that there are no signs.

Based on the results of the classic assumption test consisting of normality, linearity, multicollinearity, and heteroscedasticity, the proposed model fulfills the requirements of regression analysis for hypothesis testing.

\section{Hypothesis Testing}

This study used a multiple regression model analysis with self-actualization $\left(\mathrm{X}_{1}\right)$, self-transcendence $\left(\mathrm{X}_{2}\right)$, and meaning in life $(\mathrm{Y})$ variables. The hypothesis is accepted as long as the sig. value is $<0.05$. The results of the testing are shown in table 7 .

Table 7

The Results of T Test (Hypothesis Test)

Coefficients $^{\mathrm{a}}$

\begin{tabular}{|c|c|c|c|c|c|c|}
\hline & \multirow{2}{*}{$\begin{array}{l}\text { Model } \\
\text { B }\end{array}$} & \multicolumn{2}{|c|}{$\begin{array}{c}\text { Unstandardized } \\
\text { Coefficients }\end{array}$} & \multirow[t]{2}{*}{$\begin{array}{c}\text { Standardized } \\
\text { Coefficients }\end{array}$} & \multirow[t]{2}{*}{$\mathbf{t}$} & \multirow[t]{2}{*}{ Sig. } \\
\hline & & Std. Error & Beta & & & \\
\hline \multirow{3}{*}{1} & (Constant) & 5.443 & 4.375 & & 1.244 & .217 \\
\hline & Self-Actualization & .369 & .075 & .407 & 4.919 & .000 \\
\hline & Self-Transcendence & .323 & .071 & .374 & 4.523 & .000 \\
\hline
\end{tabular}

Table 7 showed the results of hypothesis testing for the research variables used. Decision making was carried out starting from self-actualization. Also, the results of the coefficient table showed a sig value of $0.000<0,0$, which proved the hypothesis is accepted. 
Therefore, it can be interpreted that there is a partial significant effect of self-actualization on the meaning in life of teachers.

In self-transcendence, the coefficient table results showed a sig. value of $0.000<0.05$, which proved the hypothesis is accepted. Therefore, it can be concluded that there is a partial significant effect of self-transcendence on the meaning in life of teachers. The results of the two independent variables showed a significant effect on the dependent variable. Furthermore, hypothesis testing was simultaneously conducted to determine the presence or absence of the effects of self-actualization and self-transcendence on meaning in life. These results are tested by the $\mathrm{F}$ test shown in table 8 . In addition, when the sig. value was $<0.05$, the hypothesis is accepted.

Table 8

F Test Results

\begin{tabular}{|c|c|c|c|c|c|c|}
\hline \multicolumn{7}{|c|}{ Coefficients $^{\mathrm{a}}$} \\
\hline & \multirow{2}{*}{$\begin{array}{c}\text { Model } \\
\text { B }\end{array}$} & \multicolumn{2}{|c|}{ Unstandardized Coefficients } & \multirow{2}{*}{$\begin{array}{l}\text { Standardized } \\
\text { Coefficients }\end{array}$} & \multirow{2}{*}{$\mathbf{t}$} & \multirow{2}{*}{ Sig. } \\
\hline & & Std. Error & Beta & & & \\
\hline \multirow{3}{*}{1} & (Constant) & 5.443 & 4.375 & & 1.244 & .217 \\
\hline & Self-Actualization & .369 & .075 & .407 & 4.919 & .000 \\
\hline & Self-Transcendence & .323 & .071 & .374 & 4.523 & .000 \\
\hline
\end{tabular}

a. Dependent Variable: Meaning in life.

Table 8 showed the results of the F test which is used to simultaneously analyze self-actualization and self-transcendence on the meaning in life of teacher. Meanwhile, the results in the coefficient table showed a value of $0.000<0.05$, therefore the hypothesis is accepted. It can be concluded that there is a simultaneous effect of self-actualization and self-transcendence on the meaning in life of teachers. The results of the multiple linear regression equation are as follows:

$$
\mathrm{Y}^{\prime}=\mathrm{a}+\mathrm{b}_{1} \mathrm{X}_{1}+\mathrm{b}_{2} \mathrm{X}_{2}=5.443+0.369+0.323
$$

The coefficients of the multiple linear regression equation above can be interpreted as follows: Constanta (a) of 5.443 is constant as long as the independent variables of self-actualization and self-transcendence are 0 , then the meaning in life value is 5.443 . Meanwhile, the regression coefficient of self-actualization is 0.369 , which is the value of the variable on meaning in life. This means that when each increase in self-actualization is 1 unit, then the meaning in life will increase and have a positive effect by 0.369 or $36.9 \%$. Furthermore, the increase in self-actualization will cause an increase in the meaning in life of the teacher. Meanwhile, the regression coefficient of self-transcendence is 0.323 , which is the value of the variable. This means that when each increase of self-actualization is 1 unit, then the meaning in life will increase and have a positive effect by 0.323 
or $32.3 \%$. Also, the increase in self-transcendence will cause an increase in meaning in life. These results can be seen from the Model Summary results in table 9.

Table 9

The Coefficient of Determination Results

\begin{tabular}{ccccc}
\hline \multicolumn{5}{c}{ Model Summary } \\
\hline MModel & R & R Square & Adjusted R Square & Std. Error of the Estimate \\
\hline 1 & $6634^{\mathrm{a}}$ & .402 & .389 & 3.037 \\
\hline
\end{tabular}

a. Predictors: (Constant), Self-Transcendence, Self-Actualization.

Based on the results in table 9, it can be seen that the coefficient of determination or $\mathrm{R}$ Square is 0.402 . This value showed that the coefficient is $40.2 \%$. Therefore, it indicated that self-actualization and self-transcendence simultaneously have an effect on the meaning in life of teachers by $40.2 \%$. Meanwhile, the remaining $59.8 \%$ is influenced by other variables.

\section{Discussion}

The purpose of this study is to test the self-actualization and self-transcendence as a factor that influences the meaning in life of the teacher. All the indicators of self-actualization have a positive and significant effect on that of the meaning in life of the teacher. In addition, all indicators of self-transcendence have a positive effect on meaning in life of the teacher.

The regression coefficient for self-actualization was 0.369 , indicating that when each increase is 1 unit, the meaning in life will increase by 0.369 or $36.9 \%$. Meanwhile, the regression coefficient for self-transcendence is 0.323 , indicating that when each increase is 1 unit, the meaning in life will increase by 0.323 or $32.3 \%$. Furthermore, the measurement results of the determination coefficient value was 0.402 , indicating that self-actualization and self-transcendence simultaneously have an effect on the meaning in life of teachers by 40.2\%. Meanwhile, the remaining 59.8\% is influenced by other variables outside the study.

The first finding showed that self-actualization is a variable that affects the meaning in life of the teacher with a positive coefficient of 0.369. As stated in the research methods section, self-actualization has four manifest variables namely growth, potential achievement, self-fulfillment, and encouragement needs. The results from this study support previous researches (Fave et al., 2013; Debats, 1999; Schnell, 2009; Kenrick, 2017). Fave et al. (2013) stated that self-actualization is a factor that contributes $8.5 \%$ to the meaning in life. According to Debats (1999), it is the most significant source compared to other factors. It was also reported as a factor that positively and significantly influences men 
and women (Schnell, 2009; Kenrick, 2017). Self-actualization is similar to meaning in life. Maslow (1970) reported that self-actualization is the highest development of one's talents as well as the fact that it portrays the fulfillment of one's qualities and capacities. According to these findings, it was reported that people that have achieved maximum quality and capacity tends to develop their talents and potential as well as have a high meaning of life. Based on this hypothesis, it was also concluded that meaning of life is directly proportional to the development of talents and potentials as well the fulfillment of a person's quality and capacity. People are able to actualize what they aspire based on their potentials (Maslow, 1954) thereby discovering a meaning in life.

According to the second findings, it was shown that self-transcendence affects the meaning in life of the teacher with a positive coefficient of 0.323 . In accordance with the theoretical framework, self-transcendence has seven manifest variables namely belief and religion, connectedness with higher reality, harmonization and unity with the universe, commitment to justice, conducting or creating things valued beyond one's death, consideration, forethought, helpfulness, health and fitness.

These findings support and reinforce previous findings (Schnell, 2011; Monasterio \& Cloninger, 2019; Hwang et al., 2019; Pulfrey \& Butera, 2019; Verhaeghen, 2019; Bishop, 2017; Levenson et al., 2005; Haugan et al., 2016) that self-transcendence variable has a positive effect and is an intervening factor on one's meaning in life. People with high level of self-transcendence, tend to have a high meaning in life, and vice versa. An individual with high level of self-transcendence encourages people to act altruistically, an attitude that is far from the nature of egoism, and prioritizes the interests of others.

Schnell (2011) reported that it is divided into two sub-categories, namely verbal and horizontal self-transcendence, which are both sources of a meaningful life. Vertical it is related to the need for humans to connect with the power above itself (God) through religion, while horizontal self-transcendence relates to the ability to connect with fellow humans, thereby causing a person to have a sense of social responsibility rather than personal interests.

Vertical self-transcendence is formed when the inner human nature of a person authentically connects with God, this shows immortality and human understanding (Decy \& Ryan, 2008; Madden \& Bailey, 2019). Through this connection, the work becomes meaningful because it is a place for the realization of our humanity (Beadle $\&$ Knight, 2012). This expression also offers a sense of feeling that life and work are part of the duties and devotions to God (Elangovan et al., 2010). The "exclamation" that life and work are part of devotion to God is a source of meaningfulness (Barkelaar \& Buzzanell, 2014; Cardador \& Cazza, 2012; Dik \& Duffy, 2009).

In contrast to vertical self-transcendence, horizontal is related to perfecting our relationship with the surrounding lives (Kalton, 2002; Pavlish \& Hunt, 2012). This second category refers to the concerns of others in two ways, namely in the form of a desire to share and build interpersonal relationships with colleagues (Lips-Wiersma \& Morris, 
2009) and transpersonal relationships with the surrounding reality (Reed, 2009). The idea that one's "self" is formed in relation to others leads to a meaningful life. Many authors reported that both vertical and horizontal transcendencies are based on one's religiosity or spirituality (Emmons 2005). Spirituality illustrates a strong connection between oneself and its creator. It leads people to work beyond it in order to discover true self (Amid et al., 2020). Subsequently, when an individual discovers it true self, life tends to be meaningful. The process is part of the teacher's self-development is a cause for concern because the role of education in this construct leads to failure rather than success (Conroy et al., 2012). Adapting Lee's theory (2015), four critical attributes are used by teachers in shaping their lives they are as follows experience positive emotions at work, give meaning to the work itself, work undertaken needs to have meaningful goals, and work as part of life tends to contribute to meaningful existence. Self-actualization and self-transcendence are elements that form these four critical attributes.

\section{Conclusion}

In conclusion, these findings generally show that the evidence that applies in other scientific families, be it psychology, logo-therapy, and mental health, which states that there is an influence between two independent variables, namely self-actualization and self-transcendence toward meaning in life also applies to the educational science, particularly in the meaning in life of the teacher. Therefore, it improves their professionalism, by developing and increasing the manifest variables of self-actualization and self-transcendence. Based on the results from this study, both theoretical and practical implications have been identified.

\section{Research Implications}

Self-actualization and self-transcendence play an important role in determining the level of meaning in the life of a teacher. This study discusses their influence and impact on the professional development on an ongoing basis. Teachers need to utilize the results from this research to develop meaning in their lives because it triggers and facilitates all forms of processes related to self-transcendence and self-actualization. The policy makers, both at the education unit level and the government that are in the context of the same school structure, also need to utilize the results from this study to design various programs and training for the development of meaning in life of teachers. This is because it has been proven by several authors that meaning in life has an influence on dedication, motivation, and quality of one's work. 


\section{Research Limitations and Future Research Needs}

The research samples are not large enough and is located in East Kalimantan. Therefore, it is not standard and tends not to represent the characteristics of the teachers' qualities in Indonesia as a whole. Therefore, further research with a larger sample and wider coverage area, for example Indonesia as a whole is suggested in order to examine the relationship between self-actualization and self-transcendence towards meaning in life. In addition, longitudinal research on this topic is also highly recommended because a cross-sectional study was employed.

\section{Acknowledgment}

The authors are grateful to the Directorate of Research and Community Development (DRPM) of the Ministry of Education and Culture for funding this study through the Higher Education Fundamental Research Grant (PDUPT). The author is also grateful to Ahmad Dahlan University.

\section{References}

Amid, B., Aron, L., \& Bachar, E. (2020). Selfless self-transcendence in the clinical setting as a source of self-enhancement. The American Journal of Psychoanalysis, 80(1), 16-36.

Anderson, R. A., Pizarro, D. A., \& Kinzler, K. D. (2018). Reacting to transcendence: The psychology of moral praise. Self-Transcendence and Virtue, 274-290. London: Routledge.

Baum, S. K., \& Stewart, R. B., Jr. (1990). Sources of meaning through the lifespan. Psychological Reports, 67, 3-14

Batthyany, A., \& Russo-Netzer, P. (Eds.). (2014). Meaning in positive and existential psychology. New York, N.Y.: Springer.

Beadle, R., \& Knight, K. (2012). Virtue and meaningful work. Busin Ethics Quart, 22, 433-450. doi: 10.5840/beq201222219

Berkelaar, B. L., \& Buzzanell, P. M. (2014). Cyber vetting, person environment fit, and personnel selection: Employers' surveillance and sense making of job applicants' online information. Journal of Applied Communication Research, 42(4), 456-476. doi:10.1080/00909882.2014.95 4595

Bishop, D. (2017). Fighting for an organizations heart: Self-transcendence values, moral emotions, and collective voice [Doctoral dissertation, Pennsylvania State University].

Bonanno, G.A., Papa, A., \& Lalande, K. (2005). Grief processing and deliberate grief avoidance: A prospective comparison of bereaved spouses and parents in the United States and the people's republic of China. Journal of Consulting and Clinical Psychology, 73, 86-98. 
Boyle, P. A., Buchman, A. S., Barnes, L. L., \& Bennett, D. A. (2010). Effect of a purpose in life on risk of incident Alzheimer disease and mild cognitive impairment in community-dwelling older persons. Archives of General Psychiatry, 67, 304-310.

Cardador, M. T., \& Caza, B. B. (2012). Relational and identity perspectives on healthy versus unhealthy pursuit of callings. Journal of Career Assessment, 20(3), 338-353.

Cohen, K., \& Cairns, D. (2012). Is searching for meaning in life associated with reduced subjective well-being? Confirmation and possible moderators. Journal of Happiness Studies, 13(2), 313-331.

Conroy, J. C., Lundie, D., \& Baumfield, V. (2012). Failures of meaning in religious education. Journal of Beliefs \& Values, 33(3), 309-323.

Debats, D. L. (1999). Sources of meaning: An investigation of significant commitments of in life. Journal of Humanistic Psychology, 39, 30-57. doi:10.1177/0022167899394003

Deci, E. L., \& Ryan, R. M. (2008). Intrinsic motivation and self-determination in human behavior. New York: Plenum.

Dik, B. J. \& Duffy, R. D. (2009). Calling and vocation at work: Definitions and prospects for research and practice. The Counseling Psychologist, 37, 424-450. doi: 10.1177/0011000008316 430

Elangovan, A., Pinder, C. C., \& McLean, M. (2010). Callings and organizational behavior. Journal of Vocational Behavior, 76(3), 428-440. https://doi.org/10.1016/j.jvb.2009.10.009

Emmons, R. A. (2005). Striving for the sacred: personal goals, life meaning, and religion. Journal of Social Issues, 61, 731-745.

Fave, A. D., Brdar, I., Wissing, M. P., \& Vella-Brodrick, D. A. (2013). Sources and motives for personal meaning in adulthood. The Journal of Positive Psychology, 8(6), 517-529.

Florez, I. A., Schulenberg, S. E., Lair, E. C., Wilson, K. G., \& Johnson, K. A. (2019). Understanding meaning and racial prejudice: Examining self-transcendence and psychological inflexibility in a sample of white college students. Journal of Contextual Behavioral Science, 12, 1-6.

Frankl, V. E. (2006). Man's search for meaning. Boston, M.A.: Beacon Press.

Haugan, G., Moksnes, U. K., \& Løhre, A. (2016). Intrapersonal self-transcendence, meaning-in-life and nurse-patient interaction: powerful assets for quality of life in cognitively intact nursing home patients. Scandinavian Journal of Caring Sciences, 30(4), 790-801.

Heintzelman, S. J., \& King, L. A. (2014). Life is pretty meaningful. American Psychologist, 69, 561-574. http://doi.org/10.1037/a0035049

Heintzelman, S. J., Trent, J., \& King, L. A. (2013). Encounters with objective coherence and the experience of meaning in life. Psychological Science, 24, 991-998. http://doi. org/10.1177/0956797612465878

Hicks, J. A., \& King, L. A. (2009). Meaning in life as a subjective judgment and a lived experience. Social and Personality Psychology Compass, 3, 638-653. http://doi.org/10.1111/j.17519004.2009.00193.x

Hwang, H. L., Tu, C. T., \& Chan, H. S. (2019). Self transcendence, caring and their associations with wellbeing. Journal of advanced nursing, 75(7), 1473-1483. 
Kalton, M. C. (2000). Green spirituality: Horizontal transcendence. In P. Young-Eisendrath \& M. E. Miller (Eds.), The psychology of mature spirituality: Integrity, wisdom, transcendence (pp. 187-200). London: Routledge.

Kang, Y., Cooper, N., Pandey, P., Scholz, C., O’Donnell, M. B., Lieberman, M. D \& Polk, T. A. (2018). Effects of self-transcendence on neural responses to persuasive messages and health behavior change. Proceedings of the National Academy of Sciences, 115(40), 9974-9979.

Kay, A. C., Laurin, K., Fitzsimons, G. M., \& Landau, M. J. (2014). A functional basis for structureseeking: Exposure to structure promotes willingness to engage in motivated action. Journal of Experimental Psychology: General, 143, 486-491.

Kenrick, D. T. (2017). Self-actualization, human nature, and global social problems. Society, 54(6), 520-523.

King, L. A., Hicks, J. A., Krull, J., \& Del Gaiso, A. K. (2006). Positive affect and the experience of meaning in life. Journal of Personality and Social Psychology, 90, 179-196.

Krause, N. (2007). Longitudinal study of social support and meaning in life. Psychology and Aging, 22, 456-469.

Lee, S. (2015). A concept analysis of 'Meaning in work'and its implications for nursing. Journal of advanced nursing, 71(10), 2258-2267.

Levenson, M. R., Jennings, P. A., Aldwin, C. M., \& Shiraishi, R. W. (2005). Self-transcendence: Conceptualization and measurement. The International Journal of Aging and Human Development, 60(2), 127-143.

Lips-Wiersma, M., \& Morris, L. (2009). Meaningful work' and the 'management of meaning. Journal of Business Ethics, 88(3), 491-511.

Littman-Ovadia, H., \& Steger, M. F. (2010). Character strengths and well-being among volunteers and employees. Journal of Positive Psychology, 6, 419-430.

Madden, A., \& Bailey, C. (2019). Self-transcendence and Meaningful Work. In R. Yeoman, C. Bailey, A. Madden, \& M. Thompson (Eds.), The Oxford Handbook of Meaningful Work (Oxford Handbooks). Oxford: Oxford University Press. https://oi.org/10.1093/ oxfordhb/9780198788232.013.8

Maree, J. G. (2019). Self-and career construction counseling for a gifted young woman in search of meaning and purpose. International Journal for Educational and Vocational Guidance, 19(2), 217-237.

Mascaro, N., \& Rosen, D. H. (2005). Existential meaning's role in the enhancement of hope and prevention of depressive symptoms. Journal of Personality, 73, 985-1014.

Maslow, A. H. (1970). Motivation and Personality (2nd ed.). New York: Harper \& Row Publishers. Maslow, A. H. (1987). Motivation and personality (3rd ed.). New York Harper \& Row Publishers.

Monasterio, E., \& Cloninger, C. R. (2019). Self-transcendence in mountaineering and BASE Jumping. Frontiers in Psychology, 9, 1-7. doi: 10.3389/fpsyg.2018.02686

Newman, D. B., Nezlek, J. B., \& Thrash, T. M. (2018). The dynamics of searching for meaning and presence of meaning in daily life. Journal of Personality, 86(3), 368-379. 
Nezlek, J. B., Newman, D. B., \& Thrash, T. M. (2017). A daily diary study of relationships between feelings of gratitude and well-being. The Journal of Positive Psychology, 12, 323-332.

Owens, G. P., Steger, M. F., Whitesell, A. A., \& Herrera, C. J. (2009). Relationships among posttraumatic stress disorder, guilt, and meaning in life for military veterans. Journal of Traumatic Stress, 22, 654-657.

Park, N., Park, M., \& Peterson, C. (2010). When is the search for meaning related to life satisfaction? Applied Psychology: Health and Well Being, 2(1), 1-13.

Pavlish, C. \& Hunt, R. (2012). An exploratory study about meaningful work in acute care nursing. Nursing Forum. 47(2), 113-122.

Pulfrey, C., \& Butera, F. (2016). When and why people don't accept cheating: Self-transcendence values, social responsibility, mastery goals and attitudes towards cheating. Motivation and Emotion, 40(3), 438-454.

Reed, P. G. (2009). Demystifying self-transcendence for mental health nursing practice and research. Archives of Psychiatric Nursing, 23, 397-400.

Robbins, S. P. \& Coulter, M. (2003). Management (7th ed.). N.J.: Prentice-Hall, Upper Saddle River.

Schnell, T. (2009). The sources of meaning and meaning in life questionnaire (SoMe): Relations to demographics and well-being. The Journal of Positive Psychology, 4, 483-499.

Schnell, T. (2010). Existential indifference: Another quality of meaning in life. Journal of Humanistic Psychology, 50(3), 351-373.

Schnell, T. (2011). Individual differences in meaning-making: Considering the variety of sources of meaning, their density and diversity. Personality and Individual Differences, 51(5), 667673. https://doi.org/10.1016/j.paid.2011.06.006

Schnell, T., \& Becker, P. (2006). Personality and meaning in life. Personality and Individual Differences, 41(1), 117-129.

Smith, M. J., \& Liehr, P. R. (2008). Understanding middle range theory by moving up and down the ladder of abstraction. Middle Range Theory for Nursing, 13-31.

Snow, N. E. (2018). Fundamental hope, meaning, and self-transcendence. Self-Transcendence and Virtue, 39-61. London: Routledge.

Steger, M. F., Frazier, P., Oishi, S., \& Kaler, M. (2006). The meaning in life questionnaire: Assessing the presence of and search for meaning in life. Journal of Counseling Psychology, 53, 80-93. http://doi.org/10.1037/0022-0167.53.1.80

Steger, M. F., Shim, Y., Rush, B. R., Brueske, L. A., Shin, J. Y., \& Merriman, L. A. (2013). The mind's eye: A photographic method for understanding meaning in people's lives. The Journal of Positive Psychology, 8(6), 530-542.

Steger, M. F., \& Kashdan, T. B. (2007). Stability and specificity of meaning in life and life satisfaction over one year: Implications for outcome assessment. Journal of Happiness Studies, 8, 161-179.

Steger, M. F., Oishi, S., \& Kashdan, T.B. (2009). Meaning in life across the life span: Levels and correlates of meaning in life from emerging adulthood to older adulthood. Journal of Positive Psychology, 4, 43-52. 
Suyatno, Pambudi, D. I., Mardati, A., Wantini, Nuraini, E., \& Yoyo. (2019a). The education values of Indonesian teachers: origin, importance, and its impact on their teaching. International Journal of Instruction, 12(3), 633-650.

Suyatno, S., Wantini, W., Baidi, B., \& Amurdawati, G. (2019). The influence of values and achievement motivation on teacher professionalism at Muhammadiyah 2 high school Yogyakarta, Indonesia. Pedagogika, 133(1), 105-127.

Tov, W., \& Lee, H. W. (2016). A closer look at the hedonics of everyday meaning and satisfaction. Journal of Personality and Social Psychology, 111(4), 585-609.

Tutu, D. (2007). A reflective conversation with archbishop Tutu. Gifted Education International, 23(2), 202-206. https://doi.org/10.1177/0261429407 02300208

Venter, H. J. (2016). Self-transcendence: Maslow's answer to cultural closeness. Journal of Innovation Management, 4(4), 3-7.

Verhaeghen, P. (2019). The mindfulness manifold: Exploring how self-preoccupation, selfcompassion, and self-transcendence translate mindfulness into positive psychological outcomes. Mindfulness, 10(1), 131-145.

Waytz, A., Hershfield, H. E., \& Tamir, D. I. (2015). Mental simulation and meaning in life. Journal of Personality and Social Psychology, 108, 336-355. http://doi.org/10.1037/a0038322

Westerhof, G. J., Bohlmeijer, E. T., Van Beljouw, I. M., \& Pot, A. M. (2010). Improvement in personal meaning mediates the effects of a life review intervention on depressive symptoms in a randomized controlled trial. The Gerontologist, 50(4), 541-549.

Wong, P. T. P. (2012). Toward a dual-systems model of what makes life worth living. In P. T. P. Wong (Ed.), Personality and clinical psychology series. The human quest for meaning: Theories, research, and applications (pp. 3-22). United Kingdom: Routledge/Taylor \& Francis Group.

Wong, P. T. P., \& Wong, L. C. J. (2012). A meaning-centered approach to building youth resilience. In P. T. P. Wong (Ed.), The human quest for meaning: Theories, research, and applications (2nd ed., pp. 585-617). New York, N.Y.: Routledge. 


\section{Mokytojų gyvenimo prasmę sąlygojantys veiksniai}

Suyatno ${ }^{1}$, Dholina Inang Pambudi ${ }^{2}$, Ganis Amurdawati ${ }^{3}$, Wantini ${ }^{4}$, Mei Vita Romadon Ningrum ${ }^{5}$

1 Ahmado Dahlano universitetas, Švietimo vadybos katedra, Pramuka g. 42, Sidikanas, Džokjakarta, Indonezija, suyatno@pgsd.uad.ac.id

2 Ahmado Dahlano universitetas, Pradinių klasių mokytojų rengimo katedra, Ki Ageng Pemanahan g. 19, Sorosutanas, Džokjakarta, Indonezija, dholina.pambudi@pgsd.uad.ac.id

3 Semarango universitetas, Pradinių klasių mokytojų rengimo katedra, Kelud Utara III g., Semarangas, Indonezija, ganis.amorr@gmail.com

4 Ahmado Dahlano universitetas, Islamošvietimo katedra, Pramuka g. 42, Sidikanas, Džogjakarta, Indonezija, wantini@ mpai.uad.ac.id

5 Mulawarman universitetas, Geografijos mokymo katedra, Muara Pahu miestelio Gunung Kelua g., Samarinda, Indonezija,mei_vita88@yahoo.com

\section{Santrauka}

Atsižvelgiant $\mathfrak{i}$ ateities prognozes, kad gyvenimo prasmé tiesiogiai siesis su mokytojų veiklos kokybe, svarbu ištirti tai sąlygojančius veiksnius. Literatūriniai ir empiriniai tyrimai psichologijos, logoterapijos ir psichinès sveikatos srityse atskleidé, kad savęs aktualizavimo ir savęs transcendencijos kintamieji daro įtaką žmogaus gyvenimo ir darbo kokybei bei mažina neigiamas emocijas. Šiuo metu yra labai mažai tyrimų apie mokytojų gyvenimo prasmę švietimo moksluose. Todèl šiuo tyrimu siekiama išmatuoti įtaką tarp dviejų nepriklausomų kintamųjų, būtent savęs aktualizavimo ir savęs transcendencijos, darančių itaką mokytojų gyvenimo prasmei. Duomenys buvo renkami pateikus klausimyną, kurị užpildè 100 jaunesnių vidurinių mokyklų mokytojų iš Rytų Kalimantano provincijos. Duomenys buvo analizuojami naudojant paprastą tiesinę regresiją bei kitas daugkartinės regresijos technikas, pasitelkiant SPSS statistikos programą. Rezultatai parodè, kad savęs aktualizavimas ir savęs transcendencija turèjo teigiamą ir reikšmingą poveikį mokytojo gyvenimo prasmei. Apibendrinti tyrimų rezultatai rodo, kad kitose mokslo grupėse taikomi įrodymai, tokie kaip tiriamų kintamųjų ịtaka, tinka ir švietimo tyrimuose. Šiame tyrime nuolat aptariama kintamųjų ittaka ir poveikis profesiniam tobulejjimui. Mokytojai turi pasinaudoti šio tyrimo rezultatais, nes tai palengvina visų formų procesus, susijusius su savęs transcendencija ir savęs aktualizacija. Švietimo politikos formuotojai tiek mokyklos, tiek savivaldybės ar vyriausybės mastu taip pat turi panaudoti šio tyrimo rezultatus kurdami įvairias programas ir mokymus, skirtus mokytojų gyvenimo prasmei ugdyti.

Esminiai žodžiai: gyvenimo prasmè, savęs aktualizavimas, savęs transcendencija, mokytojas.

Gauta 20200424 / Received 24042020

Priimta 20200910 / Accepted 10092020 